Brit. F. vener. Dis. (1970) 46, 510

\title{
Obituary
}

\section{A. H. Harkness, F.R.C.S., 1889-1970}

Arthur Herbert Harkness ('Harkie'), who died in London on November 12, 1970, was born in Pietermaritzburg, in Natal, in 1889. He went to school in South Africa but came to England for his medical education, at Guy's Hospital, where he won the Michael Harris prize in anatomy and qualified in 1914. In his youth he was an athlete of some distinction, playing rugby football for Natal and Guy's and cricket for Guy's. After a short period as housesurgeon he joined the Royal Navy as a Medical Officer at the beginning of the first world war and served throughout those 4 years. After demobilization he returned to South Africa for a short time but decided to make his future in this country. In 1920 he was an assessor at the Ministry of Pensions and later worked as clinical assistant at St. Peter's Hospital for Stone and the London Lock Hospital. In due course his future career was determined by his appointment as director of the V.D. Clinic at St. Peter's. Subsequently he became honorary physician to the London Skin Hospital, physician-in-charge of inpatients at the London County Council V.D. Unit at St. Charles's Hospital, honorary surgeon to the London Lock Hospital, joint director of the V.D. Clinic at St. Peter's and St. Paul's Hospital, when the two hospitals merged, lecturer in Venereology to the Postgraduate Institute of Urology, and civil consultant in Venereal Diseases to the Royal Navy. He was past president and a member of the Council of the Medical Society for the Study of Venereal Diseases.

Harkness had a long and distinguished career in his special subject. His particular interest was nongonococcal urethritis and its complications, a subject of which his knowledge and understanding were far ahead of his time and to which he contributed greatly by accurate clinical observation and careful research. He wrote many original papers of high quality on this and other subjects, culminating in his book 'NonGonococcal Urethritis' which was published in 1950. It embodied the results of an almost life-long study and was acclaimed as a classic throughout the world.

In addition to these activities he conducted a large private practice in his subject until a few months before he died. The writer, who inherited some part of this practice, has been made fully aware of the immense respect and affection which he inspired in his patients, in whose regard no one is ever likely to hold an equal place.

During his long life Harkness suffered from a number of serious illnesses, including typhoid fever and bilharzia of the bladder as a boy, pulmonary tuberculosis in 1924, and duodenal ulcer commencing in 1917 and resulting in a number of perforations and severe haemorrhages until finally cured by partial gastrectomy at the end of the second world war. Through these vicissitudes, which might have broken a lesser man, he remained his cheerful and resilient self. His health rendered him unfit for service in the armed forces in the second war, much to his regret; but he saw plenty of service during the bombing of London when he was attached to a First Aid Post at the National Heart Hospital. He was, in fact, bombed out of his own house in May, 1941.

Harkness was essentially a kind and generous man with a great capacity for friendship and a strong feeling for the less fortunate in this life, many of whom he helped in unobstrusive ways. $\mathrm{He}$ was a pioneer in his subject, an outstanding clinician, and a generous and delightful friend. $\mathrm{He}$ will be greatly missed by many people.

$$
\text { A. F. King }
$$

By the death of A. H. Harkness ('Harkie' to his many friends) venereology has lost one whose work did much to promote its evolution into a specialty in its own right in Great Britain. He made many contributions to its literature, his main interests lying in the field of non-gonococcal urethritis. His monograph on this subject incorporated the fruits of his long clinical experience and his own research into the subject. It showed that he was ahead of his time in his understanding of the prevalence and importance of this condition, but as befalls some pioneers, the significance of his contributions has sometimes been overlooked by later workers in the field.

Although I came to know him well only in the later years of his life, he was still a striking figure of a 
man, very decided in his opinions, which were usually expressed pungently. A very warm-hearted man, he was fond of company and talk and appreciative of the good things of life, although his own tastes were simple. A great character, a visit to him was always entertaining and added a spice to life. He performed many kind actions, often behind the scenes and without the recipients being aware of them, and was of help to many. He had a wide circle of friends; by his death we are all diminished.

A. E. Wilkinson

Arthur Herbert Harkness will be remembered by his many devoted friends as the most delightful, kindhearted man that one could imagine.

He was born in Natal in 1889, the son of a saddler, and could remember his mother telling him that she had seen the Prince Imperial ride through Pietermaritzburg in 1879 on his way to his death at the hands of the Zulus at Ulundi. At the age of 20, 'Harkie' left South Africa to become a medical student in London. He brought with him only a moderate academic record, but a wonderful name in athletics. He was an excellent cricketer and he excelled at Rugby football, playing for Natal and nearly becoming a Springbok. He chose Guy's as his hospital because he had seen in his local paper that they had beaten Cambridge by $20-0$ in 1907 .

He became a dresser to Arbuthnot Lane and his junior 'Chubby' Fagge, and qualifying in 1914 was appointed house-surgeon to Fripp. The day before the outbreak of the first world war he joined the Royal Naval Reserve; he was appointed surgeon lieutenant, and during the Gallipoli campaign served on the Isle of Mudros, in submarines, and in the famous $Q$ boats. On returning to Plymouth he was put in charge of thousands of sailors suffering from venereal diseases, an experience which decided his future career. The war over, he did not resume work for the F.R.C.S. which he had started in 1914, but took up hospital appointments, which led to his later post as director of the Venereal Diseases Clinic at St. Peter's. He began private practice which grew rapidly and for a period became enormous; his international reputation involved him in many lucrative trips abroad. His clinical and investigative work was of a very high order, much of it directed to the study of non-gonococcal urethritis. When his book on this subject, the result of many years of careful research and great clinical acumen, was published in 1950, it was immediately established as a classic; in the year following, the Council of the Royal College of Surgeons awarded him its Fellowship.

Following his retirement from hospital posts, 'Harkie' maintained his private practice at which he continued to within 6 months of his death.

'Harkie' had married and his wife predeceased him, but lack of a family life was compensated by his very large circle of friends and colleagues. When it was recognized that he had developed carcinoma of the bronchus many of his old friends gathered around him to help and minister to his every need. It was satisfying that he was able to pass away with no discomfort, but he expressed great sadness at the thought of leaving his dear friends.

\section{A. Dickson Wright}

